\title{
SELF-ASSESSMENT OF ENTREPRENEURIAL COMPETENCIES OF STUDENTS OF HIGHER EDUCATION
}

\author{
Helena Šlogar \\ PhD, Assistant Professor, Libertas International University, Trg J. F. Kennedy 6b, 10000 Zagreb, Croatia; \\ email: hslogar@libertas.hr
}

\author{
Nebojša Stanić \\ MSc, Senior Lecturer, Algebra University College, llica 242, 10000 Zagreb, Croatia; \\ email: nstanic@racunarstvo.hr
}

\section{Krešimir Jerin}

Professional specialist of oec., Student, Libertas International University, Trg J. F. Kennedy 6b, 10000 Zagreb, Croatia; email: kresimir.jerin@gmail.com

\begin{abstract}
Entrepreneurship has become an important academic field leading to a growing interest of scientists in the study, development and evaluation of entrepreneurial competencies of young people. Business based aspects of entrepreneurial competencies relate to the development of personality traits, student skills that influence one's personal development for successful entrepreneurs. The main purpose of this paper is to examine the entrepreneurial competencies of students during their studies and how they relate to their socio-demographic characteristics. The research was conducted in November 2019 on a sample of 172 respondents and included first-year undergraduate students of business economics and undergraduate studies of digital marketing at institution of higher education. The results of the research show a positive statistically significant correlation between all entrepreneurial competencies of students. Statistically significant differences in entrepreneurial competencies according to the gender of students were found. And finally, statistically significant differences in entrepreneurial competencies between undergraduate students of business economics and undergraduate studies in digital marketing were shown. It is expected of students with a higher degree of management competencies attending entrepreneurial education more capable of becoming future entrepreneurs. The primary contribution of this paper is to point out the need to increase students' awareness of the positive impact of entrepreneurial education programs that contribute to the development of such competencies.
\end{abstract}

Key words: entrepreneurial competencies, students, gender, study, entrepreneurship 


\section{INTRODUCTION}

In the last two decades, technological changes and globalization have significantly affected the business of enterprises. Such business environments put a high demand on staffers with developed entrepreneurial competencies, such as problem solving and decision making. Employees are notably required to be creative and innovative, to have the digital competencies necessary to operate in a changing business environment. Entrepreneurial competence influences the development of an entrepreneurial mindset and a more efficient use of students' existing knowledge and their skills. One of the strategic tasks of higher education institutions should include taking responsibility for the development of students' entrepreneurial competencies in all their years of study with the aim of a better preparation for the labor market. Through study programs, professors should help students become aware of the importance and the need to develop competencies that are crucial for their employment or the start of their own businesses. The paper analyzes the relationship between students' competencies in relation to gender and the study program in which the respondents study. Students' entrepreneurial competencies depend on their personal perception, new challenges, focus on innovative and creative ways of solving problems and the desire to succeed. These characteristics can be considered as components of traits that ultimately motivate an individual to take entrepreneurial action. The underlying assumption of the research is that knowledge and experiential learning about entrepreneurial competencies during one's studies can affect the level of self-assessment of one's competence.

The aim of this research was to examine the existence and the intensity of the relationship between the respondent's entrepreneurial competencies and their differences according to the gender and type of studies in which they study. The tasks arising from the main goal of the research are the following: to determine the connection of all entrepreneurial competencies of students, to determine the differences in entrepreneurial competencies of students, to determine the differences in entrepreneurial competencies by gender and the study program at higher education institutions. A self-assessment scale was applied that included the following components: decision making, initiative, achievement of results, leadership, empathy, team work, and integrity. Decision making can depend on a number of factors, requires taking responsibility and is considered a key entrepreneurial competence. Initiative means personal quality that shows a willingness to get things done and to take responsibility, connects to a person who notices what needs to be done in time, acts proactively and independently, but also in cooperation with others. Achieving results indicates that a person is focused on the implementation of set goals by properly organizing all available resources. Leadership encompasses knowledge in a personal, professional, business aspect that makes a difference between the gender. Empathy is important because someone empathetic is prone to teamwork and collaboration. Teamwork comprises procedures undertaken by a group of people who work together to achieve set goals. Integrity means having strong moral principles, taking responsibility for one's business decisions.

The contribution of this paper relates to the results and insights we have gained through empirical research that can help develop entrepreneurial competencies of students as part of their studies at higher education institutions. The findings obtained in this paper should find their practical application also in human resource management. Firstly, the article provides a theoretical overview 
of the relevant literature related to research on entrepreneurial competencies. It is followed by a description of the research methodology and a presentation of the obtained results. Finally, a discussion and conclusion follows, outlining the theoretical and practical implications.

\section{LITERATURE REVIEW}

A review of the literature shows that entrepreneurial competence is a multidimensional construct within different theoretical conceptualizations and the components and structures of the concept should be distinguished. Entrepreneurial competencies imply determining the relationship of individual constituent elements that may include entrepreneurial competence and form a different structure depending on the selected group. Perić, Oberman Peterka and Getoš, (2020) state that entrepreneurship is defined as one of the key lifelong competencies and represents the ability to turn ideas into real projects. As such, it includes creativity, initiative, taking responsibility, taking risks, planning and project management. Terms such as competencies, abilities, resources, skills are used in the literature and are often used interchangeably (Boyatzis, Saatcioglu, 2008; Sánchez 2011; Rasmussen et al. 2011; Lans, Baggen, Ploum, 2018). The personal characteristics of an enterprising person are initiative, creativity, ability to take risks, strong persuasive power, flexibility, imagination, independence, problem-solving ability, need for achievement, leadership ability, perseverance and a high degree of faith and ability to manage one's own destiny (Gibbu, 1987, 6). According to Kurtz and Bartram (2002:229), "competencies are sets of behaviors that are instrumental for achieving desired outcomes and results." Competence can be seen as the ability to functionally use knowledge and skills in different contexts and consists of technical knowledge, methodological knowledge, participatory knowledge and self-knowledge. In an educational context, competence is the developing general capability of persons (or organizations) to perform (such as an activity, a task, solve a problem), and when a program is successfully completed, the candidate receives a license (Mulder, 2007: 11). According to Ploum (2019) competence is an integrated ability to achieve lasting effective performance in a particular professional domain, job, role, organizational context. The term refers to coherent groups of knowledge, skills, attitudes, expertise, abilities that can be used in a business environment.

Today, no consensus has yet been reached on the very definition of entrepreneurial competence. This problem is visible in most contemporary theoretical and empirical papers through the constant need of researchers for re-conceptualizations. Research, today, has a limited possibility of generalization due to the fragmentary approach and theoretically different foundations of the researched construct. Prominent authors who have defined entrepreneurial competencies are Chandler Jansen, 1992); Man, Lau, \& Chan, (2002), and a broader discussion of entrepreneurial competencies emerges from the Mitchelmore and Rowley studies (2010, 2013). Entrepreneurial competencies are defined as underlying characteristics such as generic and specific knowledge, motive, traits, self-images, social roles and skills which result in venture birth, survival and/or growth (Bird, 1995: 51). Entrepreneurial competencies are considered a higher-level characteristic encompassing personality traits, skills and knowledge, and therefore can be seen as the total ability of the entrepreneur to perform a job role successfully (Man et al. (2002:124). Gibb (2002) states that there are a number of specific entrepreneurial competencies required for entrepreneurial activity, 
which need to be developed at the same time as core business competencies. Entrepreneurial competencies have been identified as a specific set of competencies relevant to the exercise of successful entrepreneurship (Mitchelmore and Rowley, 2010: 93).

In the European Competence Framework, entrepreneurial competences include taking responsibility for one's own behavior and actions, initiatives and reasonable risk-taking, introducing and supporting innovation, proactive action, reacting positively to change, setting and achieving goals, teamwork, motivation for success. Furthermore, entrepreneurial competence is considered to be one of the basic competences necessary for living and working in a knowledge-based society and should be provided to every individual through education (formal and non-formal) (European Commission, 2006). It is therefore crucial that universities develop entrepreneurial skills and knowledge within study programs (Sánchez 2011). Accordingly, by the end of formal education, students should have developed key competencies that enable them to behave and work as an adult, with the aim of their further development through lifelong learning and adult education programs (EC: Key Competences for Lifelong Learning: European Framework of Reference, 2006). Encouraging an entrepreneurial mindset will contribute to an increased employment of young people in the labor market.

Many authors emphasize that the main cause of non-competitiveness of the labor force in Croatia is the lack of entrepreneurial competencies in a non-entrepreneurial environment (Bejaković 2004; Sedlan König, 2013; Singer, Šarlija, Pfeifer and Oberman-Peterka, 2018). Accordingly, higher education institutions should develop student entrepreneurship competencies. Tittle, Terzidis, (2020) state that many authors define entrepreneurial competencies as a combination of competencies, traits, and other categories important to entrepreneurial activity. Sadler, (2013) points out that in the last decade the competency model has dominated the education system with an emphasis on learning outcomes. It starts from the assumption that each study program and each course provides the most appropriate place to acquire cognitive and other higher-order skills (Sadler, 2013). In this way, students develop and acquire competencies through knowledge and skills acquired in study programs. Reflection on the development of competencies provides an opportunity to analyze the factors that influence the formation of positive attitudes of students towards entrepreneurship. Rasmussen et al. (2011) state that previous research on entrepreneurial competencies has focused on the individual entrepreneur and it is unlikely that one entrepreneur possesses all the necessary competencies and credibility to start a new business. Wiek, Withycombe, Redman (2011) state that interpersonal competence encompasses the ability to motivate and facilitate collaborative research and problem solving. This capacity includes communication, negotiation, collaboration, empathy, leadership, and pluralistic and transcultural thinking skills (Kevany 2007). Researchers have found in a number of studies that personal background and characteristics such as values, attitudes, motivation, traits, and skills predispose some individuals to entrepreneurial behavior (Collins, Hanges, Locke, 2004; Stewart, Roth 2007). On the other hand, several studies suggest that emotional processes can influence decision-making behavior and judgment in a wide range of business situations which can help to understand the entrepreneurial point of view, making decisions in conditions of insecurity from individual to interpersonal 
relationships (Isen, Labroo, 2003; Cohen, 2005). Similarly, Cardon, Foo, Shepherd, Wiklund (2012) confirm that entrepreneurship implicitly contains an emotional component as well.

In the study, Kumpikaite, Ramirez, Ribeiro (2012) explored students 'skills as future employees in international companies, with the aim of showing the diversity of these skills within several cultures, specifically in students from Spain, Portugal, Lithuania, Turkey and Iran. The researched skills were divided into four groups - personal, technical, interpersonal and conceptual skills. The highest average grade is below 3.00 , which is quite a low grade and indicates the underdevelopment of all researched skills of students in different countries. Maelah, Aman, Mohamed, Ramli (2012) analyzed the impact of the 6-month accounting study program on students' soft skills development, and the skills developed included time management, oral communication and teamwork, which was expected because it is also a skill that is most often developed during formal education. According to Oberman Peterka and Alpeza, (2013) the most important role of entrepreneurship education is to develop entrepreneurial skills, behaviors and traits that will provide individuals with coping in conditions of great insecurity conditioned by globalization. In the study Sedlan König, (2013) the results confirm that a higher level of development of entrepreneurial competence increases the propensity for entrepreneurial behavior and the likelihood of starting one's own business. The research also confirms that teaching at colleges does not significantly contribute to the development of entrepreneurial competence and that extracurricular activities have a much more important role here.

The Pollard, Wilson (2014) study states that students at all levels of education, young entrepreneurs and business start-ups must practice an entrepreneurial mindset, defined with five components: the ability to think creatively, strategically, analytically and reflectively; have confidence in their abilities; ability to cooperate; have well-developed communication skills and understanding of the current business context. Mulder (2014) argues that although various attempts to implement competency-based professional learning programs have been fiercely criticized, the later development of the competency theory and research has provided new insights that have emphasized the integrative significance of competencies in professional practice. This helped to map professional fields from the domain of a specific and generic behavioral perspective. Jin and Huang, (2014) state that professional competences or soft skills have become the most essential attributes of computer science and computer engineering undergraduates. We explored ways to expose computing students to entrepreneurial ideas, to spark their entrepreneurial spirit and to enhance their professional competences during their studies. In terms of teamwork skills, according to Kaushal (2016), those individuals who love teamwork and feel comfortable working in such an environment are considered highly desirable employees. On the other hand, Mesquita, Lopes, Bredis (2016) state that actually specific traits, such as leadership, optimism, perseverance, passion, resilience, creativity, empathy, and others, are more easily found in the person of the entrepreneur. Such personality traits can be strengthened, and skills can be acquired directly through the training process in study programs (Mesquite et al., 2016).

According to Hamburg, Bucksch (2017), entrepreneurship education programs should offer students tools for creativity and adoption of digital skills for objective analysis of business ideas and communication through digital technologies, solving technical and environmental problems using 
information and communication technologies, conducting marketing strategy, using free digital tools for developing and evaluating. He also emphasizes that Europe needs eco-innovative entrepreneurs with digital skills, and thus the development of entrepreneurial attitudes should become one of the goals of education, and this requires the cooperation of all involved stakeholders in the business environment (Hamburg, Bucksch 2017). Furthermore, the results of a survey conducted in 2017 on a sample of 153 students of business economics studies showed that there are no statistically significant differences in the level of creativity among students depending on their gender and age (Šlogar, Jerin, Pendeš, 2017). Hamburg, Bucksch, (2017) state that the document "Perception and Reality: Measuring Digital Skills in Europe", which summarized the results of digital skills studies in five European countries, contains the results of one study showing that in Austria 94\% of respondents described their digital skills as "average" to "very good," but only $39 \%$ managed to pass it well on testing. In a study by Fernández Pérez, Montes Merino, Rodríguez Ariza, Alonso Galicia, (2017) suggest that students with a higher degree of emotional competence attending entrepreneurial education will have a more positive attitude towards entrepreneurship and will be considered more capable of becoming entrepreneurs. Furhermore, Widuri, (2017) maintains that through entrepreneurship education they will be educated to become individuals who have their ability and also develop entrepreneurship spirit to became a tough person and can create their own business. RezaeiZadeh, Hogan, O'Reilly, Cunningham, Murphy (2017) showed that productive thinking, motivation, interpersonal skills, and leadership are key entrepreneurial competencies to be developed in an educational context. Mars and Torres, (2018) maintain that entrepreneurial leadership education generates reveal opportunities for strengthening collegiate entrepreneurial leadership curriculum and instruction and enhancing the capacities of students to become effective leaders of change.

González-López, Pérez-López, Rodríguez-Ariza, (2020) reveal that competencies related to commitment, planning, organization, and entrepreneurial intent have a significant and direct impact on emerging entrepreneurial behavior. Likewise, entrepreneurial competencies improve the relationship between entrepreneurial intent and entrepreneurial activities. Relying on the knowledge of competencies in the analyzed studies, it can be determined that they are related to the basic framework of this research. Chahar, Hatwal, and Arya (2020) focus on the role of professional education in promoting entrepreneurial skills among female students doing professional courses in the various engineering and management institutes of Rajasthan state. Results show a positive association between professional education and entrepreneurial skill. Perić, Oberman Peterka, Getoš, (2020) did research to what extent professional education will contribute towards the development of entrepreneurial skills of students on a sample of 1272 students from 15 vocational secondary schools in the County of Osijek-Baranja. Results show no correlation between a formal program of education and the level of entrepreneurial competencies. We may well argue that students are the future enablers of entrepreneurial ventures and it is therefore essential to develop their entrepreneurial competencies during their education.

The following hypotheses are set:

$\mathrm{H} 1$ - There is a positive statistically significant correlation between all entrepreneurial competencies of students. 

Zbornik Veleučilišta u Rijeci, Vol. 9 (2021), No. 1, pp. 79-95

$\mathrm{H} 2$ - There are statistically significant differences in students' entrepreneurial competencies.

H3 - There are statistically significant differences in entrepreneurial competencies between female and male students.

$\mathrm{H} 4$ - There are statistically significant differences in entrepreneurial competencies between students studying in the undergraduate study of business economics and in the undergraduate study of digital marketing.

\section{RESEARCH METHODS}

The survey of students' attitudes is aimed at collecting data on their entrepreneurial competencies, students' self-assessment. As part of the research, questionnaires were applied to a sample of undergraduate students of business economics and undergraduate studies of digital marketing at higher education institutions. The data was collected in November 2019 at the Libertas International University and at the Algebra University Colleges where students filled out a questionnaire using paper and pencil. Before the start of the study, the respondents were given instructions and the anonymity and purpose of the research were emphasized. The response of the participants was very satisfactory and the sample included 172 students. Considering the fact that the higher education institutions that participated in the research are located in the city of Zagreb, it is considered that this is a convenience sample. The questionnaire consisted of 49 questions. Sociodemographic data referred to the gender of the participants, age, their current major. The second part deals with custom Competencies Measurement Questionnaire constructed to assess specific, pre-defined competencies. Defined competencies are: decision making, initiative, achieving results, leadership ability, empathy, teamwork and integrity. In all self-assessment questions, instruments with an associated Likert scale of five degrees were used. The paper analyzes the correlation and relationship of these components using correlation analysis, regression analysis, F-test and T-test. The analysis was performed in MS Office Excel 2016.

\section{RESEARCH RESULTS}

The results show that out of a total of 172 respondents, 42 percent of women and 58 percent of men participated in the study, which represents an approximately normal distribution of gender and data. The majority of respondents (77 percent) are from Libertas International University while 23 percent of them are from Algebra College. Furthermore, according to the type of study, 77 percent of students study in the first year of undergraduate study of business economics, while 23 percent of students study in the first year of undergraduate study of digital marketing. The division of respondents by age includes 81 percent of respondents between 19 and 21 years, while 19 percent of respondents are between 22 years or over to a maximum of 32 years. These characteristics are common for first-year students, and as respondents were randomly selected, the sample is considered representative.

Correlation and regression analysis were applied to examine the relationship between students' entrepreneurial competencies. The results are shown in Table 1 below. 
H. Šlogar, N. Stanić, K. Jerin: Self-assessment of entrepreneurial competencies of students...

Zbornik Veleučilišta u Rijeci, Vol. 9 (2021), No. 1, pp. 79-95

Table 1. Pearson's coefficient of linear correlation of students' entrepreneurial competencies

\begin{tabular}{|l|c|c|c|c|c|c|c|}
\hline $\begin{array}{l}\text { Entrepreneurial } \\
\text { competencies } \\
\text { of students }\end{array}$ & $\begin{array}{c}\text { Decision } \\
\text { making }\end{array}$ & Initiative & $\begin{array}{c}\text { Achievement } \\
\text { of results }\end{array}$ & $\begin{array}{c}\text { Ability } \\
\text { to lead }\end{array}$ & Empathy & $\begin{array}{c}\text { Team } \\
\text { work }\end{array}$ & Integrity \\
\hline Decision making & 1.00 & & & & & & \\
\hline Initiative & $\mathbf{0 . 5 8}$ & 1.00 & & & & & \\
\hline $\begin{array}{l}\text { Achievement of } \\
\text { results }\end{array}$ & $\mathbf{0 . 6 7}$ & $\mathbf{0 . 6 0}$ & 1.00 & & & & \\
\hline Ability to lead & $\mathbf{0 . 5 8}$ & $\mathbf{0 . 5 7}$ & $\mathbf{0 . 7 7}$ & 1.00 & & & \\
\hline Empathy & 0.30 & $\mathbf{0 . 3 8}$ & $\mathbf{0 . 4 7}$ & $\mathbf{0 . 5 1}$ & 1.00 & & \\
\hline Team work & $\mathbf{0 . 4 9}$ & $\mathbf{0 . 4 4}$ & $\mathbf{0 . 6 1}$ & $\mathbf{0 . 6 4}$ & $\mathbf{0 . 5 4}$ & 1.00 & \\
\hline Integrity & $\mathbf{0 . 5 1}$ & $\mathbf{0 . 4 8}$ & $\mathbf{0 . 6 3}$ & $\mathbf{0 . 6 7}$ & $\mathbf{0 . 4 4}$ & $\mathbf{0 . 5 1}$ & 1.00 \\
\hline
\end{tabular}

* blue indicates significance $p<0.05$

Source: Authors

Table 1 shows that the interrelationship between all dimensions of students' entrepreneurial competencies is positive and statistically significant. The strongest correlation was recorded between the components of leadership ability and achievement of results $(r=0.77)$, while the weakest correlation was recorded between empathy and decision making $(r=0.30)$. This confirmed hypothesis $\mathrm{H} 1$ There is a positive statistically significant correlation between all entrepreneurial competencies of students $(p<0.05)$.

To determine the differences in the evaluation of individual components in the amounts of their arithmetic means, the F-test was used to determine the differences in variances and apply the appropriate T-test. Table 2 shows the results of the F-test and the T-test between the entrepreneurial competencies of the students.

Table 2. F-test and T-test results between students' entrepreneurial competencies

\begin{tabular}{|c|c|c|c|c|c|c|c|}
\hline $\begin{array}{l}\text { Entrepreneurial } \\
\text { competencies } \\
\text { of students }\end{array}$ & $\begin{array}{l}\text { Decision } \\
\text { making }\end{array}$ & Initiative & $\begin{array}{c}\text { Achievement } \\
\text { of results }\end{array}$ & $\begin{array}{l}\text { Ability } \\
\text { to lead }\end{array}$ & Empathy & $\begin{array}{l}\text { Team } \\
\text { work }\end{array}$ & Integrity \\
\hline \multicolumn{8}{|c|}{ F-test } \\
\hline $\begin{array}{l}\text { Decision } \\
\text { making }\end{array}$ & 1.00 & & & & & & \\
\hline Initiative & 0.46 & 1.00 & & & & & \\
\hline $\begin{array}{l}\text { Achievement of } \\
\text { results }\end{array}$ & 0.36 & 0.10 & 1.00 & & & & \\
\hline Ability to lead & 0.14 & 0.03 & 0.58 & 1.00 & & & \\
\hline Empathy & 0.34 & 0.83 & 0.06 & 0.02 & 1.00 & & \\
\hline
\end{tabular}



Zbornik Veleučilišta u Rijeci, Vol. 9 (2021), No. 1, pp. 79-95

\begin{tabular}{|l|c|c|c|c|c|c|c|}
\hline Team work & 0.71 & 0.71 & 0.20 & 0.07 & 0.56 & 1.00 & \\
\hline Integrity & 0.37 & 0.10 & 0.98 & 0.56 & 0.06 & 0.21 & 1.00 \\
\hline \multicolumn{7}{|l|}{ T-test } \\
\hline $\begin{array}{l}\text { Decision } \\
\text { making }\end{array}$ & 1.00 & & & & & & \\
\hline Initiative & $\mathbf{0 . 0 0}$ & 1.00 & & & & & \\
\hline $\begin{array}{l}\text { Achievement of } \\
\text { results }\end{array}$ & 0.64 & $\mathbf{0 . 0 0}$ & 1.00 & & & & \\
\hline Ability to lead & 0.79 & $\mathbf{0 . 0 0}$ & 0.44 & 1.00 & & & \\
\hline Empathy & 0.38 & $\mathbf{0 . 0 4}$ & 0.65 & 0.10 & 1.00 & & \\
\hline Team work & 0.64 & $\mathbf{0 . 0 1}$ & 0.98 & 0.45 & 0.68 & 1.00 & \\
\hline Integrity & $\mathbf{0 . 0 0}$ & $\mathbf{0 . 0 0}$ & $\mathbf{0 . 0 0}$ & $\mathbf{0 . 0 0}$ & $\mathbf{0 . 0 0}$ & $\mathbf{0 . 0 0}$ & 1.00 \\
\hline
\end{tabular}

*blue indicates significance $p<0.05$

\section{Source: Authors}

In Table 2, unequal variances between leadership and initiative abilities and between leadership and empathy abilities were recorded only twice between the observed components, and a T-test with the assumption of different variances was used to examine the differences between their arithmetic means, while other pairs of components were used. T-test with assumption of equal variances. In the second part of Table 2, the components among which a deviation is observed, are marked. In particular, between the initiative and all other components and between integrity and all other components there is a statistically significant difference in arithmetic means, which confirmed the hypothesis $\mathrm{H} 2$ There are statistically significant differences in entrepreneurial competencies of students $(p<0.05)$.

Table 3. Arithmetic means of students' entrepreneurial competencies

\begin{tabular}{|c|c|}
\hline Entrepreneurial competencies of students & Average \\
\hline Decision making & 3.76 \\
\hline Initiative & $\mathbf{3 . 5 6}$ \\
\hline Achievement of results & 3.73 \\
\hline Ability to lead & 3.78 \\
\hline Empathy & 3.70 \\
\hline Team work & 3.73 \\
\hline Integrity & $\mathbf{4 . 0 4}$ \\
\hline
\end{tabular}

* blue indicates significance $p<0.05$

Source: Authors

Table 3 presents an overview of the arithmetic means of students' entrepreneurial competencies and the results of self-assessment show that students rated statistically significantly lower in the 
H. Šlogar, N. Stanić, K. Jerin: Self-assessment of entrepreneurial competencies of students...

Zbornik Veleučilišta u Rijeci, Vol. 9 (2021), No. 1, pp. 79-95

initiative component with an average of 3.56, while in the integrity component they rated 4.04. The analysis of differences in entrepreneurial competencies according to the gender of the respondents was performed using the F-test and the T-test.

Table 4. Results of F-test and T-test between entrepreneurial competencies according to gender of respondents and amounts of corresponding arithmetic means of student responses

\begin{tabular}{|c|c|c|c|c|c|c|c|}
\hline & $\begin{array}{c}\text { Decision } \\
\text { making }\end{array}$ & Initiative & $\begin{array}{c}\text { Achievement } \\
\text { of results }\end{array}$ & Ability to lead & Empathy & $\begin{array}{c}\text { Team } \\
\text { work }\end{array}$ & Integrity \\
\hline F-test & 0.37 & 0.44 & 0.34 & 0.64 & 0.61 & 0.84 & 0.33 \\
\hline T-test & $\mathbf{0 . 0 2}$ & $\mathbf{0 . 0 1}$ & 0.37 & 0.73 & 0.69 & 0.89 & 0.74 \\
\hline Gender & \multicolumn{7}{|c|}{ Average } \\
\hline Male & $\mathbf{3 . 8 6}$ & $\mathbf{3 . 6 7}$ & 3.77 & 3.77 & 3.68 & 3.73 & 4.06 \\
\hline Female & $\mathbf{3 . 6 3}$ & $\mathbf{3 . 3 9}$ & 3.69 & 3.80 & 3.73 & 3.74 & 4.03 \\
\hline
\end{tabular}

* blue indicates significance $p<0.05$

Source: Authors

In Table 4, the results show that the F-test did not find differences between variances of entrepreneurial competencies by gender, so a T-test with the assumption of equal variances was used to examine the differences. The T-test identified two statistically significant differences between the sexes of the respondents in the decision-making and initiative components. In both cases, male respondents were rated higher. In the decision-making component, the average score of male respondents is 3.86 , and of female respondents 3.63 , and in the initiative component, the average score of male respondents is 3.67, and of female respondents 3.39. This confirmed $\mathrm{H} 3$ There are statistically significant differences in entrepreneurial competencies between female and male students $(p<0.05)$.

Similar to the previous analysis by gender, the F-test and the corresponding T-test were used to analyze the deviation of entrepreneurial competencies between undergraduate students in the first year of business economics and the first year of undergraduate digital marketing.

Table 5. Results of F-test and T-test between entrepreneurial components by type of study and amounts of corresponding arithmetic means of student responses

\begin{tabular}{|c|c|c|c|c|c|c|c|}
\hline & $\begin{array}{c}\text { Decision } \\
\text { making }\end{array}$ & Initiative & $\begin{array}{c}\text { Achievement } \\
\text { of results }\end{array}$ & $\begin{array}{c}\text { Ability } \\
\text { to lead }\end{array}$ & Empathy & $\begin{array}{c}\text { Team } \\
\text { work }\end{array}$ & Integrity \\
\hline F-test & 0.85 & 0.22 & 0.98 & 0.44 & 0.20 & 0.82 & $\mathbf{0 . 0 1}$ \\
\hline T-test & $\mathbf{0 . 0 1}$ & $\mathbf{0 . 1 2}$ & 0.08 & 0.01 & 0.66 & 0.94 & $\mathbf{0 . 0 0}$ \\
\hline \multicolumn{7}{|c|}{ Average } \\
\hline $\begin{array}{c}\text { Business } \\
\text { economics }\end{array}$ & $\mathbf{3 . 7 0}$ & $\mathbf{3 . 5 1}$ & 3.69 & 3.72 & 3.69 & 3.73 & $\mathbf{3 . 9 8}$ \\
\hline $\begin{array}{c}\text { Digital } \\
\text { marketing }\end{array}$ & $\mathbf{3 . 9 9}$ & $\mathbf{3 . 7 0}$ & 3.88 & 3.97 & 3.74 & 3.73 & $\mathbf{4 . 2 7}$ \\
\hline
\end{tabular}

* blue indicates significance $p<0.05$ 
In Table 5, all differences in components according to the undergraduate study of business economics and the undergraduate study of digital marketing were examined using the T-test with the assumption of equal variances except for integrity where the T-test with the assumption of different variances was used (F-test $<0.05)$. Significant discrepancies were found in the arithmetic means between students of business economics and of digital marketing in three components: decision making, initiative and integrity. In all three components, students of digital marketing have a higher arithmetic mean compared to students of business economics. In the decision-making component, the arithmetic mean of students of digital marketing is 3.99, while for students of business economics it is 3.70 . For the initiative component, it is 3.70 for digital marketing students and 3.51 for business economics students. Furthermore, for the integrity component, it is 4.27 for digital marketing students and 3.98 for business economics students. This confirmed the fourth hypothesis $\mathrm{H} 4$ - There are statistically significant differences in managerial competencies between undergraduate students of business economics and undergraduate students of digital marketing $(\mathrm{p}<0.05)$.

\section{DISCUSSION}

The aim of this study was to examine students' self-assessment of entrepreneurial competences defined by components: decision making, initiative, achievement, leadership, empathy, teamwork and integrity and to check for differences in gender and type of study. Entrepreneurial competencies depend on the development of personality traits, knowledge, skills, attitudes and abilities that are necessary for individuals to act as successful entrepreneurs. The results confirm a statistically significant correlation between all dimensions of students' entrepreneurial competencies, thus confirming the first hypothesis. The strongest correlation was recorded between the components of leadership skills and achievement of results $(r=0.77)$. Also, the second hypothesis was confirmed that there are statistically significant differences in entrepreneurial competencies of students $(p<0.05)$. A discrepancy was found between the initiative and other components as well as the integrity of the other components with a statistically significant difference in the arithmetic means. Furthermore, respondents were rated in the initiative component with an average of 3.56, while in the integrity component they were rated at 4.04 . The results showed statistically significant differences between the sexes of respondents and for the decision-making component the average score of male respondents was 3.86 , and of female respondents 3.63 , and in the initiative component the average score of male respondents was 3.67 and female respondents 3.39. This confirmed the third hypothesis of statistically significant differences in entrepreneurial competencies between female and male students $(p<0.05)$. Significant discrepancies were also found in the arithmetic means between students of business economics and of digital marketing in three components: decision making, initiative and integrity. When making decisions, the arithmetic mean of students of digital marketing is 3.99 , while for students of business economics it is 3.70 . For the initiative component, it is 3.70 for digital marketing students and 3.51 for business economics students. Furthermore, for the integrity component, it is 4.27 for digital marketing students and 3.98 for business economics students. This confirmed the fourth hypothesis of statistically significant differences in managerial competencies between undergraduate students of business economics and in the undergraduate study of digital marketing $(p<0.05)$. Reflection on the obtained research 
results provides an opportunity to analyze students according to the factors that influence the formation of positive attitudes about entrepreneurship.

\section{CONCLUSION}

This study is based on the literature on key competencies and reflects the growing interest in developing the existing set of entrepreneurial competencies that creates the preconditions for designing of new study programs at higher education institutions. The obtained results are in line with previous research and indicate the need to introduce teaching courses with the aim of developing and strengthening the entrepreneurial competencies of students in all years of study programs. Therefore, it can be assumed that students who have developed entrepreneurial competencies, as a rule, will start initiatives and innovative activities, and achieve the set goals by taking responsibility. Such an approach requires an understanding of the business environment and the use of business opportunities based on the abilities, skills and knowledge that entrepreneurs will need to achieve business success.

Furthermore, the results of this research indicate the necessary development of entrepreneurial competencies within study programs at higher education institutions. Entrepreneurship education at higher education institutions plays an important role in preparing students for the labor market and in developing their careers. Entrepreneurial education should encourage a balance between theory and practice and project-based activities by involving students in the development of digital content and working in virtual networks, thus creating the necessary experience to facilitate inclusion in the labor market. This approach can be the basis for assessing the existing competencies of an individual or a team, thus highlighting areas in which additional education and training is needed.

There are also some limitations in this research. Students often give socially desirable answers through self-assessment of personal limitations. Second, the limitation relates to the type of sample because despite the relatively large number of respondents who participated in the survey, the sample is not representative of the student populace. Third, the research was conducted in a geographically limited area that includes the city of Zagreb. These arguments favor the fact that most higher education institutions are located in Zagreb in which a large number of students from all over Croatia complete their studies. The compared groups of students differ in a number of other characteristics, and these results can only be used as an indication of the possible impact on competencies, which should be further verified by the experimental method.

Given the results of the research, the study programs should ensure the acquisition of entrepreneurial competencies and expand the content to at least two compulsory courses and distribute them evenly during the five-year studies. Courses on the development of entrepreneurial competencies should necessarily include more internships and team projects in order for students to come into direct contact with business activities and in this way to develop the necessary competencies. The conducted analysis draws attention to the lack of empirical evidence on the discourse on the development of entrepreneurial competencies of young people. Not all methodological components of key competencies are elaborated in detail in the literature. The review literature 
does not provide enough empirical evidence that the researched competencies enable success in the business world. The literature has not elaborated in detail the conceptually embedded sets of interrelated competencies nor all the critical components, including the methodological components of key competencies.

The research is limited to the student populace, so future research should be conducted on a larger sample at other higher education institutions and more broadly in the industrial sectors in order to establish settings for a further comparison of research results. In order to develop entrepreneurial competencies, continuous monitoring of performance within and outside study programs is required; experimenting with learning and teaching settings; reflecting on achievements and shortcomings and adapting competencies to the needs of the labor market.

The findings gained in this research should find their practical application in human resource management. Equally, this study contributes to a better understanding of entrepreneurial competencies aiming to improve the processes arising from stakeholder interactions in the business environment. Furthermore, the results of this research indicate the importance of acquiring entrepreneurial knowledge and skills during studies, which ones students need to develop in their studies, and which are necessary for success in entrepreneurship. This study has formulated and presented the research results on this topic, achieving a conceptual scientific contribution related to the originality of setting the research goal in an insufficiently researched area; development of scientific thought on youth entrepreneurial competencies. In the applicative sense, the contribution will be accomplished by directly achieving the purpose and objectives of the research, which is the possibility of a better understanding of the entrepreneurial competencies of students for the labor market. The knowledge gained from the research will be useful to both scientists and the business, i.e. people who are direct stakeholders in the business environment. It is considered that the empirical part of the paper could be stimulating for other relevant research, which could, ultimately, contribute to the development of this area as a whole. It is also suggested to design a longitudinal research by comparing entrepreneurial competencies at the beginning of studies with those acquired at the end of studies. In future research, a sample of students in another geographical area is expected to give similar results in terms of self-assessment of entrepreneurial competencies.

\section{REFERENCES}

Bejaković, P. (2004) “Labor Force Competitiveness In Croatia: Status and Problems, U: The Competitiveness of Croatia's Human Resources”, Bejaković, P., Lowther, J. (ur.), Institut za javne financije, Zagreb, p. 1-13.

Bird, B. (1995) “Towards a theory of entrepreneurial competency”, In J. A. Katz \& R. H. Brockhaus Snr. (Eds.) Advances in Entrepreneurship, Firm Emergence and Growth, 2(1),p. 51-72.

Boyatzis, R. E., Saatcioglu, A. (2008) “ A 20-year view of trying to develop emotional, social and cognitive intelligence competencies in graduate management education", Journal of Management Development, 27(1), p. 92-108. https://doi.org/10.1108/02621710810840785

Chahar, B., Hatwal, V. and Arya, B. (2020) “ Role of professional education in developing entrepreneurial skill among female students an empirical research", International Journal of Psychosocial Rehabilitation, 24 (4); p. 441-457. https://doi.org/10.37200/ijpr/v24i4/pr201022 


\section{H. Šlogar, N. Stanić, K. Jerin: Self-assessment of entrepreneurial competencies of students...}

Zbornik Veleučilišta u Rijeci, Vol. 9 (2021), No. 1, pp. 79-95

Cardon, M. S., Foo, M. D., Shepherd, D., Wiklund, J. (2012) "Exploring the heart: Entrepreneurial motion is a hot Topic", Entrepreneurship Theory and Practice, 36(1), p. 1-10. https://doi.org/10.1111/j.1540-6520.2011.00501.x

Cohen, J. D. (2005) "The vulcanization of the human brain: A neural perspective on interactions between cognition an emotion", Journal of Economic Perspectives, 19(4), p. 3-24. https://doi.org/10.1257/089533005775196750

Collins, C. J., Hanges, P.J, Locke, E. A. (2004) “The relationship of achievement motivation to entrepreneurial behavior: A meta-analysis", Human Performance, 17 (1), p. 95-117. https://doi.org/10.1207/s15327043hup1701_5

Chandler, G. N., Jansen, E. (1992) "The founder's self-assessed competence and venture performance", Journal of Business Venturing, 7(3), p. 223-236. https://doi.org/10.1016/0883-9026(92)90028-p

Fernández Pérez, V.; Montes Merino, A. Rodríguez Ariza, L; Alonso Galicia, P. E. (2017) “Emotional competencies and cognitive antecedents in shaping student's entrepreneurial intention: the moderating role of entrepreneurship education", International Entrepreneurship and Management Journal, 15 (1), p. 281-305. https://doi.org/10.1007/ s11365-017-0438-7

Gibb, A. (1987) "Entreprise Culture - Its Meaning and Imlications for Education and Training", Journal of European Industiral Training, 11 (2), p. 2-38. https://doi.org/10.1108/eb043365

Gibb, A. (2002) "Creating Conductive Environments for Learning and Entrepreneurship: Living with, Dealing with Creating and Enjoying Uncertainty and Compleyity", Industry and Higher Education, 16 (3), p. 135-148. https://doi. org/10.5367/000000002101296234

González-López, M.J., Pérez-López, M.C., Rodríguez-Ariza, L. (2020) “From potential to early nascent entrepreneurship: the role of entrepreneurial competencies". International Entrepreneurship and Management Journal, https://doi. org/10.1007/s11365-020-00658-x https://doi.org/10.1007/s11365-020-00658-x

Hamburg, I., Bucksch, S. (2017)“Digital Skills for Eco-Innovative Entrepreneurship”, Advances in Social Sciences Research Journal, 4 (14), p. 127-136. https://doi.org/10.14738/assri.414.3435

Isen, A.M., Labroo, A. A. (2003) “Some Ways in Which Positive Affect Facilitates Decision Making and Judgment”, Emerging Perspectives on Judgment and Decision Research, p. 365 - 393. https://doi.org/10.1017/cbo9780511609978.013

Kaushal, U. (2016) “Empowering Engineering Students Through Employability Skills", Higher Learning Research Communications, 6, (4). https://doi.org/10.18870/hlrc.v6i4.358

Kevany, K. D. (2007) "Building the requisite capacity for stewardship and sustainable development", International Journal of Sustainability in Higher Education, 8 (2), p. 107- 122. https://doi.org/10.1108/14676370710726580

Kumpikaite, V., Ramírez, A.M., Ribeiro H.N.R., (2012) "Student's skills evaluation: an intercultural study", Procedia Social and Behavioral Sciences, 62, p. 208-212. https://doi.org/10.1016/j.sbspro.2012.09.034

Kurtz, R., Bartram, D. (2002) "Competency and individual Performance: Modelling the World of Work". Organizational Effectiveness, p. 227-255. https://doi.org/10.1002/9780470696736.ch10

Lans, T, Baggen, Y., Ploum, B. (2018) "Towards more synergy in entrepreneurial competence research in entrepreneurship education", A Research Agenda for Entrepreneurship Education", p. 224-242. https://doi. org/10.4337/9781786432919.00018

Man, T. W. Y., Lau, T., Chan, K. F. (2002) "The competitiveness of small and medium enterprises. A conceptualization with focus on entre preneurial competencies". Journal of Business Venturing, 17(2), p. 123-142. https://doi.org/10.1016/ s0883-9026(00)00058-6

Mitchelmore, S., Rowley, J. (2010) "Entrepreneurial competencies: A literature review and development agenda", International Journal of Entrepreneurial Behavior and Research, 16(2), p. 92-111.

Maleah R., Aman A., Mohamed Z.M., Ramli R. (2012) "Enhancing soft skills of accounting undergraduates through industrial training", Procedia - Social and Behavioral Sciences, 59, p. 541-549. https://doi.org/10.1016/j. sbspro.2012.09.312

Mars, M. M., Torres, R. M. (2018) "Developing Collegiate Student Proclivities to Entrepreneurial Leadership", Journal of Leadership Education, 17 (4), p. 110-129. https://doi.org/10.12806/v17/i4/r7 
Mesquita C., Lopes R.P., Bredis K. (2016) "Entrepreneurship in Higher Education as a Horizontal Competence", In: PerisOrtiz M., Gómez J., Vélez-Torres F., Rueda-Armengot C. (eds) Education Tools for Entrepreneurship. Innovation, Technology, and Knowledge Management. Springer, Cham, p. 223-241. https://doi.org/10.1007/978-3-319-246574_17

Mitchelmore, S., Rowley, J. (2013) "Entrepreneurial competencies of women entrepreneurs pursuing business growth", Journal of Small Business and Enterprise Development, 20(1), p. 125-142. https://doi. org/10.1108/14626001311298448

Mulder, M. (2014). "Conceptions of Professional Competence", In: Billett S., Harteis C., Gruber H. (eds) International Handbook of Research in Professional and Practice-based Learning. Springer International Handbooks of Education. Springer, Dordrecht, p. 107-137. https://doi.org/10.1007/978-94-017-8902-8_5

Oberman Peterka, S., Alpeza, M. (2013) "Koncept poduzetničkog obrazovanja - primjer Međunarodnog Centra za poduzetničke studije, Sveučilišta J.J. Strossmayera u Osijeku", Ekonomski vjesnik, 26 (1), p. 93-103.

Perić, J., Oberman Peterka, S., Getoš, Ž. (2020) "The role of vocational education in developing entrepreneurial competences of students", Ekonomski pregled, 71 (5), p. 463-492. https://doi.org/10.32910/ep.71.5.2

Ploum L. (2019) "Competencies for Sustainable Entrepreneurship“. In: Leal Filho W., Azul A., Brandli L., Özuyar P., Wall T. (eds) Decent Work and Economic Growth. Encyclopedia of the UN Sustainable Development Goals. Springer, Cham, p. 82-92. https://doi.org/10.1007/978-3-319-95867-5_36

Pollard, V., Wilson, E. (2014) “The Entrepreneurial Mindset in Creative and Performing Arts Higher Education in Australia”, A Journal of Entrepreneurship in the Arts, 3 (1), p. 3-22.

Rasmussen, E., Mosey, S., Wright, M. (2011) "The evolution of entrepreneurial competencies: A longitudinal study of university spin-off venture emergence", Journal of Management Studies, 48(6), p. 1314-1345. https://doi. org/10.1111/j.1467-6486.2010.00995.x

Recommendation 2006/962/EC on key competences for lifelong learning, (http://europa.eu/legislation_summaries/ education_training_youth/lifelong_learning/c11090_en.htm, 15.09.2020)

RezaeiZadeh, M., Hogan, M., O’Reilly, J., Cunningham, J., Murphy, E. (2017) “Core entrepreneurial competencies and their interdependencies: insights from a study of Irish and Iranian entrepreneurs, university students and academics", International Entrepreneurship and Management Journal, 13 (1), 35-73. https://doi.org/10.1007/s11365-016-0390-y

Sánchez, J. C. (2011) "University training for entrepreneurial competencies: Its impact on intention of venture creation", International Entrepreneurship and Management Journal, 7 (2), p. 239-254. https://doi.org/10.1007/s11365-0100156-x

Sadler, D. R. (2013) "Making Competent Jugments of competence", Modeling and Measuring Competencies in Higher Education, p. 13-27. https://doi.org/10.1007/978-94-6091-867-4_2

Sedlan König, Lj. (2013) "Poduzetnička kompetencija kao izvor konkurentnosti studenata na tržištu rada”, Ekonomski vjesnik, 26 (1), p. 55-70.

Singer, S., Šarlija, N., Pfeifer, S., Oberman-Peterka, S. (2018) "What makes Croatia (non)entrepreneurial country? " Results of Global Entrepreneurship Monitor (GEM) Research Croatia for 2017. (http:ww.cepor.hr/wp-content/ uploads/2017/05/GEM2016-FINAL-za web.pdf, 17.09.2020)

Stewart, W., Roth, P.(2007) "A meta-analysis of achievement motivation differences between entrepreneurs and managers", Journal of Small Business Management, 45(4), p. 401-421. https://doi.org/10.1111/j.1540-627x.2007.00220.x

Šlogar, H., Jerin K., Pendeš, D. (2017) "Značaj kreativnosti u razvijanju kompetencija mladih osoba", in Bevanda, V. (Ed.), Proceedings of Third International Scientific-Business Conference, LIMEN 2017, Leadership \& Management: Integrated Politics of Research and Innovations, December 14, Belgrade, Serbia, p. 165-173.

Tittle, A., Terzidis, O. (2020) "Entrepreneurial competences revised: developing a consolidated and categorized list of entrepreneurial competences", Entrepreneurship Education, 3 (1), p. 1-35. https://doi.org/10.1007/s41959-019$00021-4$ 
H. Šlogar, N. Stanić, K. Jerin: Self-assessment of entrepreneurial competencies of students...

Zbornik Veleučilišta u Rijeci, Vol. 9 (2021), No. 1, pp. 79-95

Jin, Y., Huang, J. (2014) "Practice of entrepreneurship education in developing professional competences for computing students", 9th International Conference on Computer Science \& Education, https://doi.org/10.1109/ iccse.2014.6926604

Wiek, A., Withycombe, L., Redman, C.L. (2011) “Key competencies in sustainability: a reference framework for academic program development", Sustainability Science, 6 (2), p. 203-218. https://doi.org/10.1007/s11625-011-0132-6

Widuri, H. (2017) "Developing the Spirit of Entrepreneurship in the High School Student", in Proceedings of the 2nd International Conference on Economic Education and Entrepreneurship - Volume 1: ICEEE, 321-325. DOI: $10.5220 / 0006885403210325$ 
Izvorni znanstveni rad

https://doi.org/10.31784/zvr.9.1.5

Datum primitka rada: 20. 11. 2020.

Datum prihvaćanja rada: 5. 2. 2021.

\title{
SAMOPROCJENA PODUZETNIČKIH KOMPETENCIJA STUDENATA NA VISOKIM UČILIŠTIMA
}

\author{
Helena Šlogar \\ Dr. sc., docentica, Libertas međunarodno sveučilište, Trg J. F. Kennedy 6b, 10000 Zagreb, Hrvatska; \\ e-mail:hslogar@libertas.hr
}

\section{Nebojša Stanić}

Mr. sc., viši predavač, Visoko učilište Algebra, Ilica 242, 10000 Zagreb, Hrvatska;

e-mail:nstanic@racunarstvo.hr

\section{Krešimir Jerin}

Struč. spec. oec., student, Libertas međunarodno sveučilište, Trg J. F. Kennedy 6b, 10000 Zagreb, Hrvatska; e-mail: kresimir.jerin@gmail.com

\section{SAŽETAK}

Poduzetništvo je postalo važno akademsko područje koje dovodi do sve većeg interesa znanstvenika za proučavanje, razvoj i ocjenu poduzetničkih kompetencija mladih. Poslovni aspekti poduzetničkih kompetencija odnose se na razvoj osobina ličnosti, studentskih vještina koje utječu na nečiji osobni razvoj za uspješne poduzetnike. Glavna svrha ovog rada je ispitati poduzetničke kompetencije studenata za vrijeme studiranja i kako su povezane sa njihovim socio-demografskim obilježjima. Istraživanje je provedeno na uzorku od 172 ispitanika u studenom 2019. godine, a obuhvaćeni su studenti prve godine preddiplomskog studija poslovne ekonomije i preddiplomskog studija digitalnog marketinga na visokim učilištima. Rezultati istraživanja pokazuju da postoji pozitivna statistički značajna povezanost između svih poduzetničkih kompetencija studenata. Utvrđeno je da postoje statistički značajne razlike u poduzetničkim kompetencijama prema spolu studenata. I na kraju, prikazane su statistički značajne razlike u poduzetničkim kompetencijama između studenata preddiplomskog studija poslovne ekonomije i preddiplomskog studija digitalnog marketinga. Očekuje se da će studenti s višim stupnjem upravljačkih kompetencija koji pohađaju poduzetničko obrazovanje smatrati se sposobnijima da postanu poduzetnici u budućnosti. Primarni doprinos ovog rada jest ukazati na potrebu povećanja svijesti studenata o pozitivnom utjecaju poduzetničkog obrazovanja koji doprinose razvoju takvih kompetencija.

Ključne riječi: poduzetničke kompetencije, studenti, spol, studij, poduzetništvo 
